Stellenbosch Theological Journal 2020, Vol 6, No 1, 357-382

DOI: http://dx.doi.org/10.17570/stj.2020.v6n1.a19

Online ISSN 2413-9467 | Print ISSN 2413-9459

2020 ๑ Pieter de Waal Neethling Trust

\title{
The anhypostasis and enhypostasis: Barth's Christological method in view of Chalcedon - its nuance and complexity
}

\author{
James P. Haley \\ Stellenbosch University \\ Stellenbosch, South Africa \\ jayphaley@gmail.com
}

\begin{abstract}
Karl Barth departs from historical Protestant orthodoxy in his unique adoption of the dual formula anhypostasis and enhypostasis to explain the union of divine and human natures in the person of Jesus Christ. For Barth, these concepts help explain why the person of Jesus Christ must not be viewed statically in his being as the God-man, but dynamically in the event of God's movement of grace towards humanity. As such, Barth applies these concepts in his analysis of the Chalcedon definition of the Jesus Christ who exists as one person with two natures. In so doing, Barth further develops Chalcedon's definition of the two natures of Christ based upon the hypostatica unio. Not only must Chalcedon be interpreted through the revelation of God in Jesus Christ as event, but also event in the union of this human essence as the Son of Man as it participates in the divine essence. ${ }^{1}$ For Barth, the emphasis is not the combining of divine and human essence into one being, but that the eternal Christ has taken to himself human essence as the one Reconciler.
\end{abstract}

\section{Keywords}

Anhypostasis; enhypostasis; Christ's human nature; Chalcedon; hypostatic union

1 Otto Weber remarks that for Barth, the revelation of God is reality based upon God's willingness to and freedom to "traverse the boundary between him and us." This is his humiliation towards us. That is, in the mode of the Son's existence "the one God became man." Humanity therefore can be like him as his adopted children in him who is the eternal Son. This is understood within the context of God's revelation as event. Moreover, God's revelation is made known to us in a form that is known to us - as humanity. Revelation is to be spoken of as an utterly free grace occurring in the world in which God, who veils himself, encounters us in a way that we can understand him, see Weber, Karl Barth's Church Dogmatics Dogmatics - An Introductory Report (Philadelphia: Westminster Press, 1953), 42-43. 


\section{Introduction}

Karl Barth's expression of the humanity of Christ as anhypostasis and enhypostasis reaches its apex in the Doctrine of Reconciliation (CD IV) where Barth develops Jesus Christ as the servant as Lord. ${ }^{2}$ More specifically stated, it is in the homecoming of the Son of Man - in Jesus Christ's exaltation as true humanity - where Barth emphasizes Christ's human nature as anhypostasis and enhypostasis in his dialogue with Chalcedon's definition of the two natures. For Barth, Chalcedon helps explain the humanity of Christ as being in action given its two-fold definition of the two natures as: unconfused, immutable and indivisible, inseparable. This establishes a critical point in Barth's ontological development of the humanity of Christ. That is, Barth now deals specifically with what it means that the human essence of Christ is brought into union with his divine essence as the exalted Son of Man in dialogue with the Chalcedon definition of the two natures. ${ }^{3}$

2 Barth, CD IV/2. While Paul Dafydd Jones agrees that the "anhypostasis/enhypostasis formula" marked a "defining moment" in Barth's early theological development, he argues that it is Barth's creative construal of the communio naturarum, communicatio idiomatum, communicatio gratiarum, communicatio operationum/apotelesmatum, that represents a highpoint of his mature Christology. For Jones, while Barth's Christology and theological epistemology "took its bearings" from Heppe's Reformed Dogmatics, in his mature Christology Barth departs from the "older dogmatics" in favor of his own reflections. Jones understands that the anhypostasis/enhypostasis pairing continues to be a "fairly incidental purpose" when it comes to Barth's positive explication of Christ's being and act. "Claims about the standing of Christ's humanity are useful, but less important than descriptions of what the humanity does - namely, participate increasingly in the ontological complex existence in Jesus Christ and play an indispensable role in the event of revelation." Paul Dafydd Jones, The Humanity of Christ: Christology in Karl Barth's Church Dogmatics (London: T \& T Clark, 2008), 147. I argue against Jones's conclusion that Barth de-emphasizes the anhypostasis and enhypostasis in his mature Christology. In this article I argue that it is in fact the anhypostasis and enhypostasis dynamic, which serves as the ontological foundation by which the hypostatica unio is actualized in the "doing" of Jesus Christ, and subsequently realized in the communio naturarum, communicatio idiomatum, communicatio gratiarum, etc. Moreover, while Barth certainly had many points of variance with traditional Reformed theology, and although he first become acquainted with anhypostasis and enhypostasis in Heppe's, Reformed Dogmatics, Barth made this theologoumenon his own in his understanding of the humanity of Christ (as clearly demonstrated in his unique coupling of these terms), which he consistently understood throughout his Church Dogmatics as the foundational aspect for understanding the union of divinity and humanity in Christ.

3 Barth takes quite seriously Chalcedon's definition of the two natures of Christ given the Trinitarian complexity of humanity being brought into union with the Logos. Michael Welker comments here that the creeds of the ancient church hold true to the notion that 
My objective in this paper is to: 1) evaluate Karl Barth's interpretation of Chalcedon given the backdrop of anhypostasis and enhypostasis; and 2) examine how Barth uses these concepts in his critique of the Chalcedon definition of two natures, which become the ontological grounding to explain the act of God's revelation of Jesus Christ in the hypostatica unio.

\section{How Did Karl Barth interpret Chalcedon?}

As the Council at Chalcedon set out to sharpen the ontological definition of Jesus Christ as very God and very man, it did so in the knowledge that the two natures of Christ remains a mystery. ${ }^{4}$ Barth likewise approaches Chalcedon with the understanding that within this union is embodied a mystery fully comprehended by God alone. ${ }^{5}$ Moreover, Barth argues that church confessions like Chalcedon are limited because they are responding to church doctrine at a specific historical point, and should not be understood as building blocks in constructing an abstract doctrine of the person of Christ. ${ }^{6}$

Although Barth judges Chalcedon's definition of the two natures to be "factually correct and necessary," he argues that it should not be understood as an absolute and comprehensive statement of the union of two natures in Jesus Christ. This is an important point to observe because while Barth agrees with Chalcedon, he argues that more must be said concerning

Christ's true humanity must be stressed along with his divinity. This position, however, resulted in some "extremely awkward doctrinal formulations that initially demanded the articulation of an (ultimately Trinitarian) self-differentiation within God without abandoning the doctrine of the one God. The task, namely, to grasp and articulate at once both the unity and difference between Jesus Christ's divinity and humanity, was to be accomplished by what is known as the doctrine of the two natures." Barth's point of departure in his own clarification of the Nicaeno-Constantinopolitanum is that Christ's divinity cannot be understood as an apotheosis, that is, as the divinization of an individual human being, see Michael Welker, God the Revealed, trans. Douglas W. Stott (Grand Rapids: William B. Eerdmans, 2013), 263-64.

4 As a general principle Barth understands the necessity and legitimacy of confessional statements and their expressions of the Christian faith, which were demanded under certain circumstances in response to new questions directed at the ambiguity of older confessions. This is how "the Nicene Creed came to stand alongside the Apostles', the Niceno-Constantinopolitan alongside the Nicene, the Ephesian and Chalcedonian alongside the Niceno-Constantinopolitan." Barth, CD I/2, 627.

5 Barth, $C D \mathrm{I} / 2,126$.

6 Barth, CD IV/1, 127. 
the union of divinity with humanity in Christ. That is, given Barth's understanding of Scripture, the doctrine of the two natures must not be understood as an autonomous one, ${ }^{7}$ but in relationship to the divine action that takes place in Jesus Christ as the revelation of God. ${ }^{8}$ Barth's concern is to more precisely explain what it means that Jesus Christ exists in two "natures." In other words, to say that the natures of divinity and humanity are simply joined together in Christ raises the obvious question: what do we mean when we speak of "nature" in this context? As we shall see, Barth further develops the concept of two natures defined at Chalcedon based upon the hypostatica unio, which is grounded in his understanding of the anhypostasis and enhypostasis of Christ's human nature.

Barth approaches the first part of Chalcedon's definition and its intent to guard against the over-emphases of Alexandria. ${ }^{9}$

The first part of the Chalcedonian definition is relevant in this connection with its safeguarding against the excesses of Alexandrian theology. One and the same Christ, the only begotten Son and Lord, is to be confessed in two natures [unconfused] and [immutable], and therefore without any idea of commixture of the two or a changing of the one into the other. ${ }^{10}$

Barth grants the mystery of this union of genuine divine and human essence, and argues that as event, "on the other side of this event and being" it must be equally emphasized that this union of the Son of God with human essence is real and indestructible. In this way Barth approaches Chalcedon through the lenses of the revelation of God in the flesh of Jesus Christ,

7 Ibid. 133.

8 Barth's conceptual understanding of divinity and humanity in Jesus Christ axiomatically points to the action of God in the revelation of Jesus Christ. "Very God and very man. If we consider this basic Christian truth first in the light of "conceived by the Holy Spirit," the truth is clear that the man Jesus Christ has His origin simply in God, that is, He owes His beginning in history to the fact that God in person became man ... He is God Himself. God is one with Him. His existence begins with God's special action; as a man He is founded in God, He is true God." Karl Barth, Dogmatics in Outline, trans. G. T. Thomson (New York: Harper and Row, 1972), 96-97.

9 Barth clearly understands the dialectic relationship between the Alexandrian and Antiochian views of the two natures defined at Chalcedon and works through the Chalcedon definition of the two natures with this in mind.

Barth, CD IV/2, 63. 
where Christ's human nature - as the Son of Man - must be understood conceptually as anhypostasis and enhypostasis in its union with the Son of God.

The mystery of the incarnation consists in the fact that Jesus Christ is in a real simultaneity of genuine divine and human essence, and that it is on this presupposition that the mutual participation is also genuine. But we must now lay an equally strong emphasis on the other side of this event and being. As it proceeds from the union and unity of the Son of God and human essence, it is also clear that the union of His divine and human essence in that two-sided participation - although it does not become unity - is a real and strict and complete and indestructible union. ${ }^{11}$

But how is this union to be understood in the context of Chalcedon? Barth argues that this union of divine and human essence in Christ is real and penetrates both sides of the equation. In other words, in Jesus Christ as the God-man, the human essence fully participates in the divine essence, and the divine essence fully participates in the essence of humanity. This is a "radical affirmation" that the divine and human essence is really and completely brought into union in Jesus Christ as the Son of God. ${ }^{12}$ Therefore, not only must Chalcedon be interpreted through the revelation of God in Jesus Christ as event, but also event in the union of this human essence as the Son of Man as it participates in the divine essence. ${ }^{13}$ The emphasis is not combining divine and human essence into one being, but that the eternal Christ who has taken to himself human essence, who exists as "the one Reconciler, Saviour and Lord." ${ }^{14}$

11 Ibid., 64.

12 Ibid.

13 Otto Weber remarks that for Barth, the revelation of God is reality based upon God's willingness to and freedom to "traverse the boundary between him and us." This is his humiliation towards us. That is, in the mode of the Son's existence "the one God became man." Humanity therefore can be like him as his adopted children in him who is the eternal Son. This is understood within the context of God's revelation as event. Moreover, God's revelation is made known to us in a form that is known to us - as humanity. Revelation is to be spoken of as an utterly free grace occurring in the world in which God, who veils himself, encounters us in a way that we can understand him, see Weber, Karl Barth's Church Dogmatics, 42-43.

14 Barth, CD IV/2, 64. 
In the second part of the Chalcedon definition Barth describes its safeguards against the excesses of Antioch where he emphasizes the positive meaning of the two natures of Christ are indivisible and inseparable, which affirm that even in their distinctiveness these two natures are totally and definitely united in Jesus Christ. ${ }^{15}$ In this context Barth argues that the reality of the divine essence unites itself to real human essence, which in turn marks the divine humiliation and the exaltation of humanity in their mutual participation in each other. As such, they "cannot be separated for all their distinctiveness." This is the single event and being of Jesus Christ which for Barth clearly speaks to the anhypostasis and enhypostasis of the Son of Man in union with the Son of God. ${ }^{16}$

If we believe in Jesus Christ, in this One, we do not decide for one element in this history to the obscuring or even exclusion of the other, but we accompany the whole course of the history in its unity and totality. The mystery of the incarnation consists in the fact that the simultaneity of divine and human essence is Jesus Christ is real, and therefore their mutual participation is also real. ${ }^{17}$

Given Karl Barth's interpretation of Chalcedon's definition of the two natures of Jesus Christ we make two observations. First, Barth agreed (at least conceptually) with the Chalcedon language that defined Jesus Christ as one person who exists in two natures, which remain unconfused and immutable, as well as indivisibly and inseparably united in their union. Barth therefore recognizes the intent of Chalcedon to guard against the excesses of both Alexandria and Antioch, which he accepts as accurate and normative for the church and orthodoxy on the whole. This is especially true in view of the irresolvable mystery of the person of Jesus Christ who exists in this union of God and humanity.

Second, we see in Barth's thinking not simply the being of Jesus Christ as the God-man, but his being as event in the union of two natures. That is, in the person of Jesus Christ is revealed the action of God in his movement toward humanity as an act of free grace. In my view Barth is not seeking to

15 Ibid. 65.

16 Ibid.

17 Ibid. 
contradict (or even correct) the Chalcedonian language of the two natures. Rather, he seeks a more precise understanding of what it means to say Jesus Christ fully embodies very God and very man in his being. That being said, Barth understands the anhypostasis and enhypostasis of Christ's human nature to undergird his insistence that the person of Jesus Christ must not be viewed statically in his being as the God-man, but dynamically in the event of God's movement of grace towards humanity.

\section{Barth's appropriation of anhypostasis and enhypostasis with a view to Chalcedon}

\section{Christ's assumption of human nature}

The dynamic of anhypostasis and enhypostasis creates in Barth's Christology an ontological precision that moves beyond the static definition of Chalcedon's two natures, where the humanity of Christ exists as a fluid movement of God's revelation in taking human essence to himself. That is, in the event of God's reconciliation with humanity ${ }^{18}$ we see the exaltation of humanity in Jesus Christ as the Son of Man. Moreover, this exaltation of humanity is not contrived humanity, nor humanity that we cannot understand as humanity, but the "human nature" of humanity, which for Barth simply means ... "that which makes a man man as distinct from God, angel or animal, his specific creatureliness, his humanitas." 19

18 Hans Vium Mikkelsen suggests that at first glance Barth's Christology appears to be very orthodox in both form and content and is structured according to Chalcedon's distinction between the two natures of Christ. Mikkelsen further argues, however, that Barth revitalizes this pattern that reformulates Chalcedon in such a radical way that it can no longer be claimed as a Christology that is a "simple" extrapolation of the tradition, see Hans Vium Mikkelsen, Reconciled Humanity: Karl Barth in Dialogue (Grand Rapids: William B. Eerdmans, 2010), 148.

19 Barth, CD IV/2, 26. With respect to the elements of reconciliation in Barth's theology, Bruce Marshall identifies three elements of significance for salvation: 1) descriptions of Jesus Christ as a particular person; 2) characteristics of the event of reconciliation that are applied to Jesus; and 3) descriptions of the immediate action and presence of God in the person of Jesus Christ made manifest in the incarnation. Marshall goes on to argue that in describing Jesus as "The Lord as Servant" or "The Servant as Lord" or "The True Witness" Barth is not using identifying descriptions of Jesus Christ. That is, these descriptions still lack the kind of descriptive uniqueness to identify a particular person, see Bruce Marshall, Christology in Conflict: The Identity of a Saviour in Rahner and Barth (Oxford: Blackwell, 1987), 121. Barth of course would disagree with this conclusion given the simple fact that the particular person (i.e., humanity) of Jesus 
With Chalcedon's definition of the two natures in the foreground, and the dynamic of anhypostasis and enhypostasis in the background, Barth explains that the human nature assumed by Christ is the same human nature (even human nature stamped by sin) that is enjoined to all created humanity. This is real human nature that the Son of God assumes to himself. ${ }^{20}$ This is adamic human nature that is brought into union with the Logos necessary for the mediator of reconciliation. Barth's conceptual language of anhypostasis and enhypostasis is quite clear and explains how the Logos assumes to himself sinful human nature (that which is not real), and makes that human nature reality by virtue of its union with the Son of Man. This points back to Barth's understanding of Jesus Christ as the first Adam, as the genuine human being. This is foundational to Barth's understanding of the Christological concept "vere Deus which declares the equality of Jesus Christ with God, but with an explanation of the vere homo which declares His equality with us." ${ }^{21}$

Barth argues: how can Christ be the true mediator of reconciliation for sinful humanity if he does not himself share in the same sinful flesh? Yet in his human nature Christ committed no sin during his lifetime. In this dialectical sense Jesus Christ must be understood as existing both in the likeness of sinful human flesh, and not in the likeness of sinful flesh. ${ }^{22}$ Like us as our brother, Jesus is also unlike us in the human nature that he assumes. He is like us in our creaturely form and its determination by sin and death in our opposition to God. This is the form of humanity that has fallen away from God, which exists under the wrath of God as adamic

Christ cannot be understood, or described, outside its union with the divine Logos in whose particular existence he enjoys as anhypostasis and enhypostasis in this union.

20 Berkouwer categorizes Barth as an emphatic defender of the impersonal human nature of Christ, and raises the question "whether in the confession of the "vere deus" and in our theological reflection on it, are we confronted by the doctrine of the 'anhypostasy?" However, Berkouwer recognizes that Barth understands the human nature of Christ to exist in and through the Word, and concludes that by means of the "anhypostasy" Barth wants to resist the danger of Ebionitism which proceeds from the personality, the apotheosis, of a man who so impressed people that they cry out "He is God." Therefore, according to Barth, the point at issue is not at all a form of Docetism, but is a rejection of an abstract, isolated existence of the man Jesus of Nazareth, see G. C. Berkouwer, The Person of Christ, trans. John Vriend (Grand Rapids: W.B. Eerdmans, 1954), 309.

21 Barth, CD IV/2, 26.

22 Barth, CD IV/2, 27. 
humanity. This is the situation of Christ's humanity - who as the good and genuine creature of God - is the flesh that the Son of God made his own when he became human essence. In this way Christ is very man in this contradiction of human existence. Otherwise, he would not be like we are in this totality, and he could not be our Lord and saviour as our head. ${ }^{23}$

But the fact that He is not only $a$ true man, but the true man [der wahre Mensch], is not exhausted by His likeness with all other men. He is not only completely like us, but completely unlike us - and it is only when we add this complementary truth that we realise the full meaning of the vere homo as it applies to Him. But the unlikeness consists in what must necessarily become, and has become, of "human nature" when $\mathrm{He}$ assumed it in likeness with us, of flesh when it became His. It relates to the particularity of the history which took place when $\mathrm{He}$ became man, and still takes place as $\mathrm{He}$, the Son of God, is man. ${ }^{24}$

In this dialectic relationship with us, Jesus Christ is totally different from us because in human existence there also took place an "exaltation of the humanity which as His and ours is the same."25 That is, Jesus Christ shares our human essence, he does so on a higher level, which means that while his humanity is like ours, it is also not like ours. ${ }^{26}$ Christ's human nature is distinct from ours both in degree and in principle, both quantitatively and qualitatively. ${ }^{27}$ As the Son of God, the divine subject humiliated himself in

23 Ibid.

24 Ibid; KD IV/2, 28.

25 Ibid., 28.

26 Dietrich Bonhoeffer sounds a very similar chord with Barth here with respect to Jesus Christ as the new humanity. "Jesus Christ pro me is pioneer, head and firstborn of the brethren who follow him. This pro me is thus related to the historicity of Jesus Jesus Christ is for his brethren by standing in their place. Christ stands for his new humanity before God. But if that is the case, he is the new humanity. Because he acts as the new humanity, it is in him ... and he is in it. Because the new humanity is in him, God is gracious towards it in him." Dietrich Bonhoeffer, Christ the Center, trans. Edwin H. Robertson (San Francisco: HarperSanFrisco, 1978), 48-49.

27 Barth, CD IV/2, 28. 
becoming humanity. And in the same action this humanity was exalted as the Son of Man in this indissoluble union. ${ }^{28}$

As this divine subject which became a man - humiliating Himself as such - He exists in a history which cannot be that of any other man. What else can the Son of God who humbled Himself as man become and be but the Son of Man who is not divinised but exalted [erhöhte] to the side of God? What else can the Lord who became a servant become and be but the servant who became a Lord? This is the secret of the humanity of Jesus Christ which has no parallel at all in ours. This is the basis and power of the atonement made in Him on this side - as it is seen below from man." ${ }^{29}$

Barth emphasizes that the divine being of Jesus Christ was sent by the Father to this world of humanity. He took to himself the lowliness of humanity in his obedience to the Father as Jesus of Nazareth. Ontologically speaking (and in view to the Chalcedon definition of homoousia), Jesus Christ manifests both the humiliation of deity as the Son of God, and the exaltation of humanity as the Son of Man, without distinction in time or event. ${ }^{30}$ This marks the distinction of Jesus Christ as the mediator of reconciliation, the keeper of God's covenant as very God and very man. This in turn prepared the way for Bath's development of the correlation

28 Barth emphasizes that as the Son of Man, this exaltation of humanity is made manifest in Jesus Christ. Barth can now clearly emphasize the exaltation of the humanity of Christ based upon the coalescence of humility and exaltation revealed in Jesus Christ as the mediator of reconciliation.

29 Barth, CD IV/2, 28; KD IV/2, 29.

30 Karl Barth understood the exaltation of humanity to also apply very personally to believers in Christ. In his well-known sermons entitled Deliverance to the Captives, which were primarily preached at the prison at Basel, Barth does not hesitate to express the "freedom" enjoyed by those who experience the reality of the promise of Christ: "Nevertheless I am continually [with thee]." Barth encourages his listeners "Do you realize that the Bible is a book of freedom, and that divine worship is a celebration of freedom?" ... This is what happens to us when we leave behind the "with myself" and break through to the conviction: "nevertheless I am continually with thee. What kind of a 'thou' is this? Is it a man? Yes indeed, someone with a human face, a human body, human hands and a human language. One whose heart bears sorrows - not simply his own, but the sorrows of the whole world. One who takes our sin and our misery upon himself and away from us." Karl Barth, "Nevertheless, I am continually with Thee," in Deliverance to the Captives (Westport: Greenwood, 1961), 16-17. 
between the humanity of Christ with the Chalcedon definition of the two natures based upon the ontology of anhypostasis and enhypostasis.

Barth now addresses the ontological implications concerning the eternal Logos who assumes to himself human nature. For Barth, the incarnate Christ does not simply consist of two natures which exist "side by side or even within one another", because there is only one God the Son. There is no one and nothing that exists either alongside or in him. ${ }^{31}$ This is the dialectical union of divine essence and human essence in the Son of God. He exists both inconceivably (above the world) as God and conceivably (of the world) as a man. ${ }^{32}$ It is the unio hypostatica that takes precedence in Barth's thinking with a clear view towards the anhypostasis and enhypostasis of Christ's human nature. At bottom, Barth is concerned with the union "made by God in the hypostasis (the mode of existence)" of the Son of God and the man Jesus of Nazareth. ${ }^{33}$

But however, we may understand and expound these points in detail, they all rest on the "hypostatic" union, i.e., the union made by God in the hypostasis (the mode of existence) of the Son. They all rest on the direct unity of existence of the Son of God and the man Jesus of Nazareth. And this is produced by the fact that in Himself this One raises up to actuality, and maintains in actuality, the possibility of a form of human being and existence present in the existence of the one elect Israel and the one elect Mary. He does this by causing His own divine existence to be the existence of the man Jesus. ${ }^{34}$

Barth distinguishes the unio hypostatica from all other unifications and unions, which must be understood in its utter uniqueness; that is, it is sui generis, which can only be understood in terms of itself. ${ }^{35}$ As such, this union of divine and human essence cannot to be understood as an analogy to the triune union of the Father, Son and Holy Spirit in the one essence

31 Ibid., 50.

32 Barth, $C D$ IV/2, 50; KD IV/2, p. 53.

33 Ibid., 51.

34 Ibid.

35 Barth makes specific reference to Heinrich Heppe's Reformed Dogmatics, from which he develops the unio hypostatica in this context, but with the caveat that "I am not slavishly bound to it in detail." Barth, CD IV/2, 52. 
of God. ${ }^{36}$ This is an important distinction because the union of divinity and humanity in Jesus Christ is not a unio coessentialis that consists in a twofold existence of the same being. This must be true because the divine essence is superior to the human essence that it assumes to itself in Jesus Christ. "It is the unity of the one existence [Einheit der einen Existenz] of the Son of God with the human being and essence which does not exist without Him. Above all, although the Son is equal with God the Father and God the Holy Ghost, He is not of equal being and essence with the humanity assumed by Him." ${ }^{37}$

This is the foundational point for Barth in understanding the union of divine and human essence in Jesus Christ; that the "divine humanity of Jesus Christ is not a relationship between two equal or even similar partners." This is a union based upon the mercy of God demonstrated by his inconceivable condescension in turning towards the antithetical character of humanity by becoming real humanity in Jesus of Nazareth. ${ }^{38}$ Moreover, because this union of divinity and humanity is not one of a unio essentialis, Barth goes so far as to ask whether the incarnation of God in Jesus Christ is not in fact surpassed by his ongoing providential care which he never relinquishes. ${ }^{39}$

Barth argues that the union of divinity and humanity must not be understood as an analogy, as in the union of two people that presupposes two self-existent beings. Such an analogy is impossible because the union of the Logos with humanity is also defined as anhypostasis. ${ }^{40}$ As the one who is both creator and Lord of heaven and earth, the Son of God adds to his divine existence human existence with the expressed purpose to bridge

36 See Benjamin Leslie on the objectivity of God and human subjectivity in Barth Trinitarian theology, Benjamin C. Leslie, Trinitarian Hermeneutics: The Hermeneutical Significance of Karl Barth's Doctrine of the Trinity (New York: Peter Lang, 1991), 228.

37 Barth, CD IV/2, 52; KD IV/2, 56.

38 Ibid. See Robert Jenson on Barth and the Triune God's free choice in the incarnate Son, see Jenson, Systematic Theology, Vol. 1. The Triune God (New York: Oxford University Press), 140.

39 Barth, CD IV/2, 52-53. Barth's answer is that as enhypostasis, the humanity of Christ is sharply differentiated from the divinity of Jesus Christ through which God maintains and rules the world in virtue of his creative action as God. He therefore maintains his own existence in relation to the world, and the world in relation to God.

40 Ibid. 
the antitheses between God and humanity. ${ }^{41}$ This is the movement of God in the Word becoming flesh - in the egeneto.

In effect Barth shifts the Chalcedon argument of the unio hypostatica from one of strict being to one of being and event made manifest in the revelation of Jesus Christ. As being and event, the incarnation of Christ supersedes all earthly analogies in his direct revelation of God. In other words, there is no earthly relational analogy that corresponds to the anhypostasis and enhypostasis of the human nature that Christ assumes to himself in the event of his revelation. ${ }^{42}$

Moreover, Christ is the head of his church which manifests the form of his earthly body. ${ }^{43}$ And as his church, this people exist as Christ's "earthlyhistorical" form of existence. ${ }^{44}$ Although there is no earthly analogy for these concepts, Barth draws upon a heavenly/earthly analogy of the church and its union to Christ. That is, Barth employs the ontology of anhypostasis and enhypostasis to express the relationship of the church (in human essence) to that of its head (in divine essence). In this relationship the church does not exist independently from its head, nor is it of the same essence as its head, but it exists in virtue of its union with its head - in the existence of Christ. ${ }^{45}$ It is in the anhypostasis and enhypostasis relationship of the church with its head; in Christ, which in fact determines the reality of his church. ${ }^{46}$

41 Ibid., 54.

42 Barth, $C D$ IV/2, 58; KD IV/2, 62.

43 Barth takes quite seriously the relationship between Jesus Christ and his church. That is, in his humanity Jesus Christ became indissolubly united to his church as its head and source of being. For Barth, one could not speak of the Christian church and not understand and describe it as "the living congregation of the living Lord Jesus Christ." Barth, "The Church: The Living Congregation of the Living Lord Jesus Christ," in God Here and Now (New York: Harper \& Row, 1964), 61.

44 Barth, CD IV/2, 59.

45 Michael Welker argues that for Barth, the church is joined to Christ through his work of reconciliation through the power of the Holy Spirit. In other words, God awakens and gathers the church to himself by the power of the Holy Spirit, which is realized in its union with Christ, see Welker, "Karl Barths und Dietrich Bonhoeffer Beiträge zur zukünftigen Ekklesiologie." Zeitschrift für Dialektische Theologie 22, no 2(2006): 120-137.

46 Alister McGrath argues that the life, work, and doctrine of the church are totally dependent upon this presupposition: it is through Christ that she proclaims that true and authentic reconciliation with God as a present reality for those within the 
It is of human essence - for the church is not of divine essence like its Head. But it does not exist in independence of Him. It is not itself

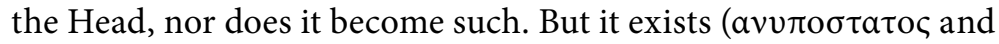

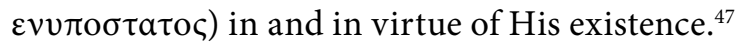

It is the antithesis of the heavenly and the earthly - united together in Jesus Christ - which emerges as the fundamental principle for Barth in the context of Chalcedon. ${ }^{48}$ That is, divine essence alone is the subject in the event of this union. "It is apparent at once that divine and human cannot be united as the essence of the one and the same subject." For Barth, regardless of how we may define divine and human essence, we do violence to either one or the other if we do not define them with a clear distinction - even antithesis. $^{49}$

Therefore, in the union of divinity and humanity in Jesus Christ is actualized the assumption of human essence by the Son of God while maintaining his own divine essence. This means that Jesus Christ exists as the Son of God while also participating in human essence, and he exists as the Son of Man while also participating in the divine essence of the Son of God. On both sides there is a genuine and true participation. As such, the divine essence of the Son of God "gives to the human essence of Jesus of Nazareth a part in His own divine essence as the eternal Son" who remains co-equal with the Father and the Holy Spirit in the God-head. ${ }^{50}$ This is the grace of God made manifest in Jesus of Nazareth, in the anhypostasis and enhypostasis of human essence, which is exalted through its union with divine essence in the event of Jesus Christ.

church. "The Christian faith and the Christian church alike stand or fall with the authenticity of the proclamation that God has established a new relationship between Himself and sinful man, and the life of faith stands or falls with the knowledge of the present actuality of this relationship." Alister McGrath, "Justification and Christology: The Axiomatic Correlation between the Historical Jesus and the Proclaimed Christ." Modern Theology 1, no. 1 (1984): 46.

47 Barth, CD IV/2, 59.

48 As Michael Welker notes, Barth's theological grounding is based upon the movement of God's revelation and the foundation of faith's orientation. Because God is in heaven, we are to expect God's action, God's engagement in the reality of our lives "from above, straight down from above." Michael Welker, Creation and Reality (Minneapolis: Fortress Press, 1999), 34.

49 Barth, CD IV/2, 61.

50 Ibid., 62. 
Barth further argues that according to the witness of Scripture, the actuality of Jesus Christ is realized as both God and humanity together in a true and genuine union. As the mediator of the covenant, however, the human essence of Christ is not to be understood as the subject. The human essence is not an individual possibility which has existence and became; that has actuality in and by itself. ${ }^{51}$ Nor can divine nature, Godhead as such, be considered as the subject of atonement and incarnation because he exists in and with the existence of the Father, Son and Holy Spirit. Barth argues that in John 1:14 we are not told that the Godhead, the divine nature, became flesh, but the divine Logos becomes flesh. He is the subject in and with his divine essence who exists and is actual God the Son. ${ }^{52}$ It is in this sense that Barth rejects the notion that the person of Jesus Christ is constituted in two natures defined as divine and human. For Barth, the "doctrine of the two natures" cannot stand on its own as a true statement.

Its whole secret is the secret of John 1:14 - the central saying by which it is described. Whatever we may have to say about the union of the two natures can only be a commentary on this central saying. Neither of the two natures counts as such, because neither exists nor is actual as such. Only the Son of God counts, He who adds human essence to His divine essence thus giving it existence and uniting both in Himself. In Him, and Him alone, they were and are united. ${ }^{53}$

Therefore, the emphasis of the incarnation must fall on the divine subject as the Son of God, which gives precedence to the doctrine of the hypostatica unio over the communio naturarum. However, the question must be raised: is Barth using a minimalist view of the hypostatical unio with a contradictory view towards Chalcedon when expressing Jesus Christ as the union of very God and very man, rather than one person with two natures? ${ }^{54}$

51 Barth, CD IV/2, 65.

52 Barth, CD IV/2, 65-66.

53 Barth understands the Godhead as such to be meaningless unless understood in terms of its modus of existence as Father, Son and Holy Spirit. With respect to the human nature of Christ, it too becomes meaningless absent its union with the divine essence in the Logos. The significance of the anhypostasis and enhypostasis is quite evident here. As expressed in John 1:14, it is the Son of God who is the subject in uniting to humanity to himself, a humanity that only enjoys reality as the object of this union in the Logos.

54 This is the conclusion drawn by Paul Dafydd Jones. 
I argue that Barth is not expressing the union of the divine Logos with humanity in a way that contradicts the Chalcedon definition, and certainly not with a minimalist view towards Chalcedon. What we see here is Barth's emphatic defence of the incarnation that must be understood in light of the revelation of God in Jesus Christ - as event. This defines in a nutshell the essence of how Barth understands the revelation of Jesus Christ who in his being not only reveals the Godhead, but acts on behalf of the Godhead. ${ }^{55}$ As the Son of God he is the divine subject who moves towards humanity by taking true humanity to himself; humanity that is - and must be anhypostasis and enhypostasis. Although he remains unchanged in his divine essence in union with the Father and the Holy Spirit, the Logos has brought human essence into union with himself. The divine Son of God is always the subject of this union, and the human essence that he assumed to himself is always the object of this union. And it is the anhypostasis and enhypostasis of Christ's humanity that serve to regulate and keep separate the divine essence from human essence, while at the same time maintaining their indissoluble union. This is how Barth understands the hypostatica unio.

\section{The mutual participation of divinity and humanity}

But how does Barth understand conceptually this union of divine and human essence that is accomplished by the Son of God in his incarnation? First, Barth argues that this is not a rigid union like two planks that are joined together where each retains a separate identity in this union and remain alien to each other. "The Son of God takes and has a part in the human essence assumed by Him by giving this a part in His divine essence. And the human essence assumed by Him takes and has a part in His divine by receiving this from Him." ${ }^{56}$ Barth argues that this mutual

55 Jones argues that while Barth accepts the importance of Chalcedon with respect to its defence of Christ's divinity, he shows little interest in one of its key conceptual elements, the concept of nature (physis) used to explain Christ as being fully divine and fully human. Instead, he adopts what Jones describes as a "decidedly minimalist alternative;" that is, Christ as vere Deus vere homo. Jones recognizes in this "alternative" an indication of Barth's interest in developing a Christological course "beyond Chalcedon" that is based upon the biblical narratives and a highly actualized ontology, see Jones, The Humanity of Christ, 7.

Barth, CD IV/2, 70 . 
participation of divinity and humanity must be understood as the Son of God who acts in this event. ${ }^{57}$ As such, the Son of God, the one of divine essence, also assumes human essence to Himself. Barth, however, is careful to distinguish this mutual participation of divinity and humanity in Jesus Christ between the 1) participation of Christ's divine essence in his human essence from 2) the participation of his human essence in the divine. That is, Christ's divine essence is that which is originally proper to him; whereas Christ's human essence is adopted by him, and assumed by his divine essence. ${ }^{58}$ Their mutual determination therefore remains distinct because: "The determination of His divine essence is to His human, and the determination of His human essence from His divine. He gives the human essence a part of His divine, and the human essence receives this part in the divine from Him." ${ }^{59}$

For Barth mutual cannot be understood to mean interchangeable. The relationship between the two natures is not reversible because each has its own role. Barth emphasizes that this union is a real history that takes place from "above to below and also from below to above." However, it takes place from above to below first - and only then from below to above - in the coalescence of the self-humiliated Son of God with the exaltation of humanity. In this coalescence of humility and exaltation, we see Christ as the subject of this history. This is true not simply because the divine and human essence in Christ are different by definition, but because they have a different character in their mutual relationship. The Son of God exists as

57 Bruce McCormack clearly points out that for Barth, what God is and what he can do is learned through the "following-after" of his movement into history. That is, what it means to be human must be learned from the history of the man in who human nature is restored into what God intended it to be. In the incarnation of Jesus Christ is made manifest in time the eternal being-in-act. Therefore, the second person of the trinity did not "become" the "Logos as human" at the point of the incarnation. The second person of the trinity (eternally speaking) already has a name, which is Jesus Christ. McCormack argues that in this understanding Barth does not depart from the Chalcedon formula, but has reinterpreted the significance of its central categories in terms of a "historicized" ontology; that is, and understanding of God's being as a being-in-act, see McCormack, "The Ontological Presupposition of Barth's Doctrine of the Atonement," in Charles E. Hill and Frank A. James III (eds.), The Glory of the Atonement: Biblical, Historical \& Practical Perspectives: Essays in Honor of Roger Nicole (Downers Grove: Intervarsity Press, 2004), 360.

58 Barth, CD IV/2, 70-71.

59 Ibid., 71. 
Jesus exists, and Jesus exists as the Son of God exists. As very man Jesus Himself is the Son of God and therefore of divine essence, God by nature. ${ }^{60}$ The human essence that is assumed by the Son of God "became and is divine essence." This human essence, however, is not divinized in this union. "Jesus Christ became and is the Son of Man only because and as the Son of God took human essence and gave it existence and actuality in and by Himself." 61

Although the humiliation of the Son of God means that he became humanity, his exaltation as the Son of Man does not mean that he became God. Barth asks: how could Christ become what he already was from all eternity as the Son of God, and that which he did not cease to be as the Son of Man? He is one and the same as Son of God and Son of Man. Otherwise, he did not accomplish his humiliation as the Son of God, which would bring into question how he could be the reconciler and mediator. Therefore, the exaltation of the Son of Man, who was also the Son of God, is not the divinization of his human essence in his becoming humanity. ${ }^{62}$

This is how Barth understands the twofold differentiation of divine and human essence and their mutual participation in Jesus Christ. The divine essence of the Son of God is wholly that which gives, and the human essence of the Son of Man is that which is exalted to existence and actuality only in and by him. ${ }^{63}$ This is the quintessential essence of Barth's understanding of the anhypostasis and enhypostasis in the human nature of Christ. We cannot look at the two natures of Christ as though they simply existed side by side. We cannot speak of Jesus Christ in words that refer exclusively to his divine or human essence. In the one Jesus Christ belongs everything that is divine essence and everything that is human essence. ${ }^{64}$

Within the enclosure of the hypostatic union, it is the divine nature that illumines and penetrates the human essence so that all the attributes of the divine nature of Jesus Christ may be ascribed to his human nature.

60 Ibid., 71.

61 Ibid.

62 Ibid., 72.

63 Ibid.

64 Ibid., 74. 
Although this does not involve any alteration to this human essence, it means that "this nature experiences the additional development (beyond its humanity) of acquiring and having as such all the marks of divinity, of participating directly in the majesty of God, of enjoying in its creatureliness every perfection of the uncreated essence of God." ${ }^{65}$ True salvation therefore is realized in Jesus Christ in so far as this takes place and is actualized in him. It is this entrance of divine essence into the world of humanity that directly accomplishes its reconciliation with God in this new and eternal life. ${ }^{66}$

\section{The exaltation of the Son of Man}

Barth understands that the Christ of Scripture remains immutable in his divine essence, even as he humiliates himself as the Son of Man in his election. This is how Christ addresses and directs his divine essence to his human essence. ${ }^{67}$ In effect, human essence also becomes the essence of God as he assumes and adopts it in Jesus Christ. In this way the divine essence of Jesus Christ condescends towards human essence with an "open-handed generosity." ${ }^{68}$ Moreover, Christ exercises grace by "becoming the Son of Man as the Son of God, and therefore in the strictest, total union of His nature with ours." This is accomplished in the power of his divine nature, which is addressed to human nature in acquiring this form. This explains why the participation of the two unions in Jesus Christ is only one-sided that of the human in the divine. Indeed, the first instance is that of the divine in the human where it has its "ultimate depth and unshakable solidity" as a participation of the human in the divine. This is God who bound himself to humanity and must come first because it is the presupposition of the other. ${ }^{69}$

65 Ibid., 77.

66 Ibid. This is the consistent theology of Karl Barth that finds its source in the Scripture and is confessed by Reformed Creeds that "God reveals Himself to man in Jesus Christ" in whom the people of God have a head. He is the Lord Jesus Christ, God and man (God and sinful man) united as one; see Barth, The Knowledge of God and the Service of God According to the Teaching of the Reformation, trans. J. L. M. Haire and Ian Henderson (London: Hodder and Stoughton, 1960), 57-59.

67 Ibid., 85 .

68 Ibid., 87.

69 Ibid. 
Given the presupposition that God has bound himself to humanity in acquiring the form of humanity, Barth asks what does it mean in the human sphere that "all the fullness of the Godhead dwells in Him bodily."70 Barth answers that it is human essence as determined by the electing grace of God. It is human essence confronted by the divine essence in that God willed to be and became humanity as well as God. That is, without becoming divine, the humanity of Christ is an essence that exists in and with God, being adopted, sanctified, and ruled by him. This is the "exaltation which comes to human essence in the one Jesus Christ." ${ }^{71}$

For Barth, this exaltation of human essence is best expressed in the unio hypostatica given the anhypostasis and enhypostasis of Christ's human nature. This is the movement of God's grace towards humanity; his willing condescension in the union of divine essence with human essence in Christ. It is the exaltation of Jesus Christ as the Son of Man that follows the humiliation of Christ as the Son of God, which is fulfilled in it. ${ }^{72}$ As the recipient of the electing grace of God, the human essence of Christ is affirmed in its exaltation as the true essence of humanity. ${ }^{73}$

Barth understands that grace is divine giving and human receiving. It is therefore the grace of God that was actually received by Jesus Christ as the Son of Man. Moreover, in Christ's existence as humanity, because he exists as a creature, he exists as God exists. ${ }^{74}$ "His existence as man is identical with the existence of God in His Son. God in His Son becomes man, existing not only as God, but also as man, as this One, as the Son of

70 Ibid.

71 Ibid., 88 .

72 Ibid.

73 Ibid., 89.

74 Ibid., 90. John Webster offers a simple but enlightening insight. Above all, Barth distances himself from apologetic investigation of the possibility of Christian Dogmatics by referring to some general realm of human piety or some theory of knowledge or ontology. He rejects anything in the way of an extra-theological argument in favour of theology. Barth's response to apologetics is not simply a denial of generally available knowledge of God upon which revelation of Christ builds. Barth is concerned to refute the principle that knowledge can be found in an ontology or anthropology as the basic science of human possibilities. Underlying all this is Barth's theological realism of the ontological supremacy of God in his self-revelation, see John Webster, Barth's Ethics of Reconciliation. (Cambridge: Cambridge University Press, 1995), 23-26. 
Man, Jesus of Nazareth." 75 As the Son of Man his origin and determination is determined by the grace of God alone which derives entirely from his own divine origin. ${ }^{76}$ In all of this Barth makes it clear that the Son of Man finds his ontological bearings as anhypostasis and enhypostasis in union with the divine nature of Christ.

In all this we are again describing the enhypostasis or anhypostasis of the human nature of Jesus Christ. We may well say that this is the sum and root of all grace addressed to Him. Whatever else has still to be said may be traced back to the fact, and depends upon it, that the One who is Jesus Christ is present in human nature is the Son of God, that the Son is present as this man is present, and that this man is none other than the Son. ${ }^{77}$

Therefore, it is the duality of anhypostasis and enhypostasis that regulates the humanity of Christ by first affirming his humanity as the same humanity as us (yet without sin), and secondly by guarding against the divinization of his human essence. In this way, Christ assumes humanity in its full being, just as he enjoys full being as eternal God. "Godhead surrounds this man like a garment, and fills Him as the train of Yahweh filled the temple in Is. 6. This is the determination of His human essence."78 This is the grace of God - revealed in the action of God - through the being of the Son of Man. As such, the human essence of the Son of God is empowered by the New Testament concept of the exousia where, as the Son of Man, he has freedom and is empowered to act according to the electing grace of God. ${ }^{79}$

75 Barth, CD IV/2, 90.

76 Ibid., 91.

77 Ibid.

78 Ibid., 94. Paul Metzger argues that not only did Barth's employment of the anhypostasis and enhypostasis model set aside the time-eternity dialectic, but it would provide him with categories needed to solve the dilemma of their strict opposition in their dialectic relationship. This establishes the basis for Barth to develop a truly incarnational model of Christology, one that would enable him to "set forth a positive yet dialectical conception of the engagement of God and humanity, and Christ and culture." Paul L. Metzger, The Word of Christ and the World of Culture - Sacred and Secular through the Theology of Karl Barth (Grand Rapids: William B. Eerdmans, 2003), 39.

79 Ibid. 
Yet, as Barth insists, there is no reason to question the pure humanity of Jesus Christ in relation to this empowering of his human essence. ${ }^{80} \mathrm{In}$ Jesus of Nazareth is revealed absolute divine power and authority without imputing omnipotence and divinity to his human essence. In this event the human essence of Jesus Christ acquires divine power and authority to conquer death. ${ }^{81}$ In the human death and passion of Jesus Christ is found the final depth and self-humiliation of God as he secretly entered and traversed in this world. Yet the glory of Jesus Christ is the exaltation of humanity to God. In the obedience of his human life is his triumph in his work of atonement. ${ }^{82}$

We observe here the structural union between God and humanity in Jesus Christ where the divine and the human work together but are not interchangeable. As anhypostasis and enhypostasis the human nature has no capacity to act upon the Logos. Therefore, the divine Logos must act upon the human nature of Christ in this union. This is the movement of God from above towards humanity in the person of Jesus of Nazareth, which is realized in genuine and historical action.

\section{Conclusion}

We start by saying that Karl Barth's thoughtfulness and energetic thinking in his development of the exaltation of the Son of Man is a great theological achievement. It not only provides unique insight into the ontological character of the humanity of Christ, but it also brings to a great theological

80 Ibid., 98.

81 Ibid., 99.

82 Ibid., 116. I greatly appreciate John Webster's comments with respect to Karl Barth's language of Christ's reconciliation as being a present and real work. That is, throughout the doctrine of reconciliation Barth quietly argues against theological existentialism. For Barth, "questions of the 'realty' and 'meaning' of Jesus are a function of Jesus' presence and activity, not of the historicity of the person of faith." Barth rejected the liberal theological notion that Christological language needs to be supplemented by descriptions of "cognitive, interpretive, or experiential acts." Rather, Barth believed that our knowledge of Jesus Christ is ingrained within his reality as the "risen, ascended, and self-communicative one." More than any other modern theologian Barth shakes himself free from the presupposition that Jesus is past, see John Webster, Barth's Moral Theology - Human Action in Barth's Thought (Grand Rapids: Eerdmans, 1998), 128. 
crescendo Barth's expression of the anhypostasis and enhypostasis of Christ's human nature. While Barth recognizes the Chalcedon language to successfully safeguard against the extremes of Alexandria and Antioch, he pursues a path beyond Chalcedon, not as a contradiction, but as a more precise way to understand what it means to say Jesus Christ fully embodies very God and very man in his being. Grounded in the anhypostasis and enhypostasis, Barth expresses the person of Jesus Christ, not in the static being of very God and very man - but dynamically - in the event of God's movement of grace towards humanity.

But Barth's greatest achievement in this context is his expression of the dynamic of the Son of Man who is brought into union with the Son of God through the revelation of Jesus of Nazareth. Barth uses the backdrop of anhypostasis and enhypostasis to express the hypostatic unio as the ontological grounding for the union of divinity with humanity. Moreover, and interestingly so, Barth also uses anhypostasis and enhypostasis to express how the body of the church is brought into union with its head, Jesus Christ, to enjoy real subsistence in this union. Barth draws here a heavenly/earthly analogy of the church and its union in Christ. In this way the church of Christ manifests the form of Christ's earthly body (human essence), which does not exist independently from its head. Therefore, its union with Christ as its head (divine essence) determines the real existence of the church, which in Barth's thinking is quite naturally expressed as anhypostasis and enhypostasis.

\section{Bibliography}

Barth, Karl 2010. Church Dogmatics, Vol. I, Part 2. Translated by G. T. Thomson and Harold Knight. Peabody: Hendrickson Publishers.

- 2010. Church Dogmatics, Vol. IV, Part 1, Translated by G. T. Thomson and Harold Knight. Peabody: Hendrickson Publishers.

- 2010. Church Dogmatics, Vol. IV, Part 2, Translated by G. T. Thomson and Harold Knight. Peabody: Hendrickson Publishers.

- 1990. Die Kirchliche Dogmatik, Vol. IV, Part 2. Zürich: Theologischer Verlag. 
- 1961. Deliverance to the Captives. Westport: Greenwood.

- 1972. Dogmatics in Outline. Translated by G. T. Thomson. New York: Harper and Row.

- 1960. The Knowledge of God and the Service of God According to the Teaching of the Reformation. Translated by J. L. M. Haire and Ian Henderson. London: Hodder and Stoughton.

- 1964. God Here and Now. New York: Harper \& Row.

Berkouwer, G.C. 1954. The Person of Christ. Translated by John Vriend. Grand Rapids: W.B. Eerdmans.

Bonhoeffer, Dietrich 1978. Christ the Center. Translated by Edwin H. Robertson. San Francisco: HarperSanFrisco.

Jenson, Robert W 1997. Systematic Theology, Vol. 1. The Triune God. New York: Oxford University Press.

Jones, Paul Dafydd 2008. The Humanity of Christ: Christology in Karl Barth's Church Dogmatics. London: T \& T Clark.

Leslie, Benjamin C 1991. Trinitarian Hermeneutics: The Hermeneutical Significance of Karl Barth's Doctrine of the Trinity. New York: Peter Lang.

Marshall, Bruce 1987. Christology in Conflict: The Identity of a Saviour in Rahner and Barth. Oxford: Blackwell.

McCormack, Bruce 2004. “The Ontological Presupposition of Barth's Doctrine of the Atonement." In The Glory of the Atonement: Biblical, Historical \& Practical Perspectives: Essays in Honor of Roger Nicole, edited by Charles E. Hill and Frank A. James III. Downers Grove: Intervarsity Press, 346-366.

McGrath, Alister 1984. "Justification and Christology: The Axiomatic Correlation between the Historical Jesus and the Proclaimed Christ." Modern Theology 1, no. 1 (1984): 45-54.

Metzger, Paul Louis 2003. The Word of Christ and the World of CultureSacred and Secular through the Theology of Karl Barth. Grand Rapids: William B. Eerdmans. 
Mikkelsen, Hans Vium 2010. Reconciled Humanity: Karl Barth in Dialogue. Grand Rapids: William B. Eerdmans.

Weber, Otto 1953. Karl Barth's Church Dogmatics - An Introductory Report. Philadelphia: Westminster Press.

Webster, John 1998. Barth's Moral Theology - Human Action in Barth's Thought. Grand Rapids: Eerdmans.

- 1995. Barth's Ethics of Reconciliation. Cambridge: Cambridge University Press.

Welker, Michael 1999. Creation and Reality. Minneapolis: Fortress Press.

- 2013. God the Revealed. Translated by Douglas W. Stott. Grand Rapids: William B. Eerdmans.

— "Karl Barths und Deitrich Bonhoeffers Beiträge zur zukünftigen Ekklesiologie." Zeitschrift für Dialektische Theologie, 22 no 2(2006):120-137. 
